\title{
PRICE THEORY
}


Other Macmillan books by D. W. Pearce

$$
\text { Cost-Benefit Analysis }
$$

Cost-Benefit Analysis: Theory and Practice (with Ajit K. Dasgupta)

\section{Capital Investment Appraisal} (with C. J. Hawkins)

The Economics of Natural Resource Depletion (editor) 


\title{
PRICE THEORY
}

\author{
W. J. L. RYAN \\ Professor of Political Economy, University of Dublin, Eire
}

\author{
REVISED BY \\ D. W. PEARCE \\ Professor of Political Economy \\ University of Aberdeen
}

\section{REVISED EDITION}




\section{(C) W. J. L. Ryan $195^{8}$}

Revised edition (C) W. J. L. Ryan and D. W. Pearce 1977

All rights reserved. No part of this publication may be reproduced or transmitted, in any form or by any means, without permission.

First edition 1958

Reprinted 1960, 1961, 1962, 1964 (twice), $1965,1966,1967,1969$

Revised edition 1977

\section{Published by}

THE MACMILLAN PRESS LTD

London and Basingstoke

Associated companies in New York Dublin

Melbourne Johannesburg and Delhi

ISBN 978-0-333-17913-0 ISBN 978-1-349-17334-1 (eBook)

DOI 10.1007/978-1-349-17334-1

Text set in 10/12 pt Photon Baskerville, printed by photolithography, and bound in Great Britain at The Pitman Press, Bath

This book is sold subject to the standard conditions of the Net Book Agreement.

The paperback edition of this book is sold subject to the condition that it shall not, by way of trade or otherwise, be lent, resold, hired out, or otherwise circulated without the publisher's prior consent, in any form of binding or cover other than that in which it is published and without a similar condition including this condition being imposed on the subsequent purchaser. 


\section{CONTENTS}

Preface to the Revised Edition $\quad$ xi

Preface to the First Edition xiv

1 Preferences and Consumer Equilibrium 1

1.0 The Household and the Consumer 1

1.1 Preference and Indifference 2

1.2 Commodity Space 5

1.3 General Axioms of Choice 7

1.4 Deriving the Indifference Map of a Consumer 9

1.5 A Digression: Lexicographic Orderings 12

$\begin{array}{lll}1.6 & \text { Convex Preferences } & 14\end{array}$

1.7 Some Properties of Indifference Curves 17

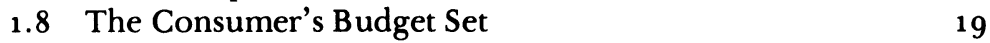

1.9 Consumer Equilibrium 20

1.10 Some 'Pathological' Cases $\quad 21$

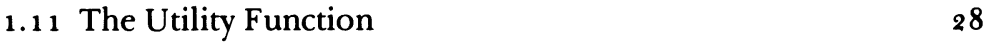

2 Demand Functions $\quad 31$

2.0 Income-Consumption Relationship 31

2.1 Income Elasticity of Demand 34

2.2 Price-Consumption Relationship $\quad 36$

2.3 The Demand Curve $\quad 3^{8}$

2.4 Price Elasticity of Demand 42

2.5 Price Elasticity and Total Revenue 44

2.6 Income and Substitution Effects $\quad 46$

(a) The Hicks Approach $\quad 47$

(b) The Slutsky Approach $\quad 49$

2.7 Redefining 'Normal', 'Inferior' and 'Giffen' Goods 51 
2.8 On Various Demand Curves 52

2.9 Substitutes and Complements $\quad 56$

2.10 Revealed Preference $\quad 5^{8}$

2.11 Some 'Pathological' Demand Curves 62

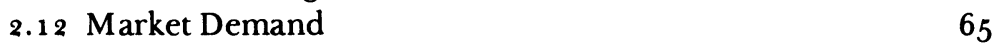

2.13 Market Demand: Aggregation Problems 66

3 Short-Run Sales Plan of the Firm: The Production Function 70

$\begin{array}{ll}\text { 3.0 Purchase and Sales Plans } & 70\end{array}$

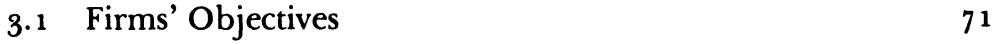

3.2 Planning Periods $\quad 72$

3.3 The Production Function: Linear Case 73

3.4 The Production Function: Smooth Case 79

3.5 The Convexity of Isoproduct Curves 80

3.6 The Law of Non-Proportional Returns 82

3.7 Linearity and Product Curves 86

4 Short-Run Sales Plan of the Firm: Cost Functions and $\begin{array}{ll}\text { Equilibrium } & 88\end{array}$

$\begin{array}{lll}4.0 & \text { Cost Minimisation } & 88\end{array}$

$\begin{array}{lll}4.1 & \text { Changes in Relative Input Prices } & 89\end{array}$

$\begin{array}{lll}4.2 & \text { Cost Functions } & 92\end{array}$

$\begin{array}{lll}4.3 & \text { Output and Substitution Effects } & 97\end{array}$

4.4 Equilibrium of the Firm 99

4.5 The Response of Sales Plans to Changes in Product $\begin{array}{ll}\text { Price } & 104\end{array}$

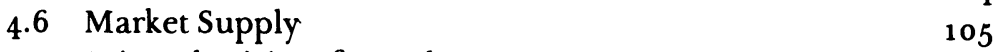

4.7 Price-Elasticity of Supply $\quad 106$

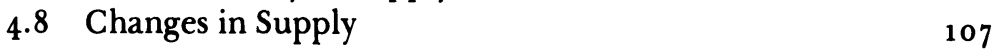

5 Long-Run Sales Plan of the Firm: Production, Cost and Supply $\begin{array}{ll}\text { Functions } & 109\end{array}$

5.0 The Long Run 109

5.1 Returns to Scale $\quad 110$

5.2 The Cobb-Douglas Production Function 112

$\begin{array}{ll}5.3 & \text { Indivisibilities } \\ & 113\end{array}$

5.4 Long-Run Production Possibilities $\quad 114$

5.5 Long-Run Costs $\quad 116$

\begin{tabular}{lr}
5.6 & Choice of a Sales Plan \\
\hline 118
\end{tabular} 
5.7 The Intermediate Period

5.8 The Multiproduct Firm

6 The Determination of Relative Product Prices

6.o Supply and Demand

6.1 Price Determination: Short-Run

6.2 Short-Run Price Determination: A Simple Algebraic Approach

6.3 Short-Run Demand and Supply Analysis: Applications to Price Control and Taxation

6.4 Price Determination: Long-Run

6.5 Long-Run Demand and Supply Analysis: Applications

6.6 Long-Run Supply: Changing Input Prices

6.7 Short-Run and Long-Run Demand

7 The Purchase Plan of the Firm

7.0 Introduction

7.1 Short-Run Demand for One Variable Input

7.2 Input Price-Elasticity

7.3 The Effects of Parameter Changes

7.4 The Short-Run Demand Curve: Two Variable Inputs 160

7.5 The Long-Run Demand Curve

7.6 The Total Demand Curve for an Input

7.7 The Firm's Demand for a Durable Good

8 The Sales Plan of the Consumer: The Supply of Effort 172

8.o Consumption Time and Work Time

8.1 Optimal Allocation of Time

8.2 The Supply Curve of Labour

8.3 Income and Substitution Effects

8.4 The Effort-Demand for Labour 180

8.5 Long-Run Supply

8.6 The Sales Plan for the Services of Land

9.1 The Savings Plan: Money and Bonds

9.2 The Savings Plan: Wider Portfolio Choice 
$\begin{array}{lll}\text { 10.0 Relative Wage-Rates } & 216\end{array}$

10.1 The Determination of the Relative Price of a Durable Good

10.2 The Pricing of the Services of Durable Goods

10.4 A Note on Differences in Efficiency between Units of the 'Same' Input

10.5 A Note on 'Economic Rent'

10.6 The Rate of Interest

11 The Determination of Relative Prices: General Equilibrium

11.0 General and Partial Analysis

11.1 The General Consequences of an Economic Event

11.2 The Uses of General Analysis

11.3 A Formal Approach to General Equilibrium

11.4 The Existence of General Equilibrium Prices

11.5 The Stability of General Equilibrium Prices

12 Market Behaviour and Market Morphology

12.0 The Methodology of Market Models 259

12.1 Pure Competition

12.2 Perfect Competition

12.3 A Classification of Markets

13.0 The Nature of Monopoly

13.1 The Equilibrium of the Monopolist

13.2 The Objectives of the Monopolist

13.3 Monopolistic Price Discrimination 282

13.4 Advertising

13.5 Potential New Entrants

13.6 Long-Run Decreasing Costs $\quad 289$

13.7 Genesis of Monopoly and Maintenance of Monopoly 290 
14.1 Short-Run Equilibrium under Monopolistic Competition

14.2 Long-Run Equilibrium under Monopolistic Competition

14.3 Full-Cost or Average-Cost Pricing

15 Monopsony and Monopsonistic Competition

15.0 Monopsonistic Markets

15.1 Equilibrium under Monopsony

16 Oligopoly

16.0 The Nature of Oligopoly

16.1 The Cournot Model

16.2 Leadership Models

316

16.3 The Kinked Oligopoly Demand Curve

16.4 Collusive Oligopoly

329

16.5 Game Theory and Oligopoly

17 Bilateral Monopoly

17.0 Price-Taker Context

17.1 Price-Maker Context

18 Normative Price Theory

18.0 Introduction

18.1 Consumer's Surplus: The Concept

18.2 Consumer's Surplus: The Marshallian Approach

18.3 Hicks's Four Measures of Consumer's Surplus

18.4 Compensation Tests

18.5 Pareto Optimal Allocations

18.6 The Optimality of Perfect Competition

18.7 The Problem of Second Best

378

18.8 Public Goods

18.9 External Effects 


\section{PREFACE TO THE REVISED EDITION}

In the preface to the first edition of Price Theory (1958) Professor Ryan remarked that he had used 'only the traditional tools of analysis', and that 'were this book being written five or ten years later the emphasis given to the various tools would have to be completely reversed'. Fifteen years later the tools of analysis have certainly changed as far as the professional economist is concerned. Linear and non-linear programming, game theory, linear algebra and the traditional weapons of the calculus now play a very much larger role in research and in teaching than they did some years ago. The modern university and polytechnic student is expected to accommodate at least some of these techniques, but it seems right to say that the average student is still largely nonnumerate and is likely to remain so for some time, although standards are clearly rising. The modern author does therefore have a choice. He can write for the numerate and reach only a small proportion of the student audience, perhaps hoping that the increasing preponderance of numerate textbooks will give the non-numerate more incentive to learn some mathematics. Or he can write for the non-numerate, gain the larger audience, but at the cost of some rigour, some elegance and the omission of topics which can best be treated mathematically.

I have, in this revised edition of Professor Ryan's justly famous work, tried to steer a middle path. What I have done is to use some mathematical language in the belief that the biggest obstacle to learning numerate economics is the jargon and not the mathematical manipulation of equations. What I have not done, except occasionally - and only then where a non-mathematical approach has also been used - is to operate with mathematics. In this way I hope the reader will gain some of the flavour of modern approaches without being faced with the impenetrable barrier of mathematical limitation.

The actual process of revising the first edition turned out to be far 
more complex than I imagined. Both Professor Ryan and the publishers merit my apologies and indebtedness for being so patient with me. The problem lay in the fact that Professor Ryan's original treatment was almost 100 per cent self-contained. It had a logical sequence which, though I strived not to, I fear I have broken. On the other hand, it was difficult to see how any change from the original edition could preserve the unique features of that edition. The only real loose ends in the original edition were contained in Chapter 12 entitled 'Some Further Problems'. The topics in that chapter are now integrated in the main body of the text.

In making other changes I have been deliberately subjective and there is no question that I shall be criticised for having included some things, elaborated on others, and omitted still others. The biggest issue was whether to include a substantial section on 'new' theories of the firm. Had I done this the book would have been longer than it is now, and my feeling was that $(a)$ it would have departed even further from Professor Ryan's original aims, and (b) it would have been redundant in face of some excellent recent volumes which have concentrated on this issue. In consequence, the main changes have been to introduce linearity into the chapters on consumer theory and on cost and production theory; to extend the general equilibrium chapter; to 'update' chapters where I have felt this expedient; and to add a new chapter on the normative uses of price theory - that is, welfare economics. While this is a small list, the result has been a substantial change, although I have done little to change Professor Ryan's meticulous treatment of firm equilibrium under various market forms. The chapters have also been rearranged slightly, although here again it was Professor Ryan's careful juxtaposition of chapters in logical sequence that was a dominant feature of the original edition. I can only hope that some of the logical rigour and value of Professor Ryan's original approach, which I cannot hope to emulate, remains.

Lastly, I have written for the market, and this has sometimes meant that I have taken a fairly neutral approach to issues on which I have, in fact, the most decided opinions. In particular I have recorded the conventional approach to the 'efficiency' of market systems, although reference to some of my other work will show that I find this notion of efficiency very unattractive. There is nothing novel in the content of the revised edition: it has all been said before. I can only hope that the arrangement of the material and the exposition will appeal. My debts are therefore fairly obvious and include all writers on economic issues. 
A special debt is owed to Christopher Nash of Southampton University who read many of the new sections and commented in his usual invaluable way. And, of course, I owe an immense debt to Professor Ryan for his assistance and advice during the preparation of this manuscript. As always, my greatest debt is to my family. None of these people, least of all my family, bear any responsibility for the errors which no doubt remain.

D. W. P.

University of Leicester

April 1976 


\section{PREFACE TO THE FIRST EDITION}

It is tempting to begin by defining the scope of economics and describing the methods by which economic truths are customarily pursued in academic circles. The temptation is acute for an economist, for the fascination of economics with its own scope and method verges on neurosis. It is with reluctance, therefore, that we do not deal with these topics explicitly. We shall not prejudice their importance, however, if we define economics as the kinds of thing that economists habitually talk about, and its methodology as the way in which they customarily do so.

Economists generally describe certain decisions that are taken by individuals who are acting on their own behalf, or as agents, in a free society, and attempt to explore some of their effects. The kinds of decision that interest economists are those which lead to a purchase or to a sale. In the Western world, those who decide to buy and sell may be classified roughly into households, firms and the various agencies of government. Each household decides what commodities and services to buy and when, where and in what quantities to buy them. These decisions make up the purchase plan of the household. Each household will also have a sales plan setting out the things that its members have decided to sell and the quantities, prices and places at which they will be sold. The sales and purchase plans of the household will be related to one another, for the sums of money that the members of the household get from selling their labour or lending their savings or renting their land generally constitute the fund out of which they buy the goods and services of everyday consumption.

Similarly, each firm in the economy must decide what goods to produce and sell and when, where and the quantities in which to sell them. All these decisions make up the sales plan of the firm. In addition, each firm must decide what things to use in making its products, and 
when, where, how, and in what quantities to use them. All decisions of this kind are summarised in its purchase plan.

The purchase and sales plans of the firms are not independent of one another, for firms buy in order to sell. The sums of money that they earn by selling the goods they produce are used directly or indirectly to pay for the things they require to assist in their production and sale. We would expect, too, some relation between the plans of households and those of firms. The things that firms plan to sell must be similar to those which households plan to buy, and the things that firms plan to buy must be more or less the same as the things that households or other firms are planning to sell.

In a free world the implementation and revision of these plans affect almost all facets of human life and endeavour. As economists, however, we are primarily interested in how these plans determine both relative prices and price levels. As firms and households act on the plans they have made, the relationship between prices may alter: butter may become more expensive than nails or bread less dear as compared with jam. And almost all prices might rise as they have done since 1939 , or fall as they did in the early 1930's. These twin effects are inextricably and indistinguishably linked together, but if we are to grasp their nature we must examine each in isolation. In this book we are primarily concerned with the determination of the relationship between the prices of the things that are bought and sold.

This book is intended as a text-book for students who are planning to specialise in economics. I have tried to state all the assumptions explicitly and to keep the analysis rigorous. The analysis may occasionally seem to be a trifle self-conscious, for I believe that it is important for students to learn not only what economists do but why and how they do it. There are frequent summaries of the analyses, and I hope that these will be more helpful than they are tedious. I do not think that there is anything that is original in the contents of this book, but there may be some originality in the form in which they are presented.

In elaborating the theory of relative prices, I have used only the traditional tools of analysis. While these tools are suffering a rapid obsolescence, they still do a better job than the prototypes of the tools which may soon supplant them and which are briefly described in the final chapter. It is not improbable, however, that were this book being written five or ten years later, the emphasis given to the various tools would have to be completely reversed. 
xvi

I am deeply indebted, either directly or indirectly, to all economists who have written on the theory of price. If I make no attempt to acknowledge my debts in detail, it is because they are too numerous and because I have forgotten the transactions in which many of them originated. I wish to express my gratitude to Professor G. A. Duncan, Professor A. T. Peacock, Professor G. L. S. Shackle, Dr. A. W. H. Phillips, Mr. Jack Wiseman and Mr. F. P. R. Brechling who read the manuscript and made many valuable suggestions and criticisms, and to the students in the London School of Economics and Political Science and in the University of Dublin who forced me to strive after clarity both in thought and expression.

TRINITY COLLEGE

W. J. L. RYAN

DUBLIN 